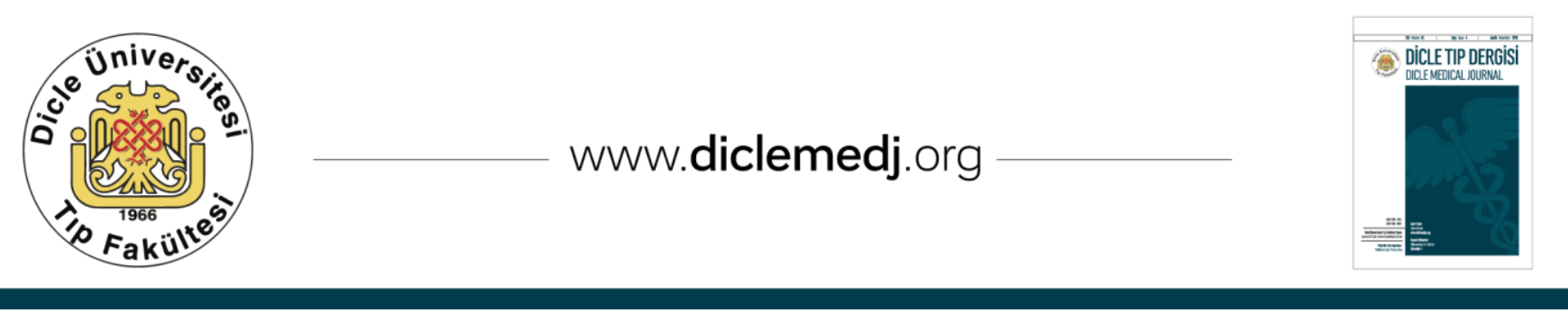

Özgün Araștırma / Original Article

\title{
Moleküler Hpv Uygulanan Olgularda Hpv Sonuçları ile Patolojik Materyallerin Karşılaştırılması
}

\author{
İbrahim Halil Erdoğdu1 \\ 1 Aydın Adnan Menderes Üniversitesi Tıp Fakültesi Patoloji Ad. Aydın, Türkiye ORCID: 0000-0002-5445-2649
}

Geliş: 12.01.2019; Revizyon: 25.01.2019; Kabul Tarihi: 04.02.2019

Öz

Amaç: Birçok kanser gelişiminde bazı HPV tipleri çok önemli rol oynamaktadır. Serviks kanserlerinin hemen tamamı HPV'ye bağlı olarak gelişmektedir. Uzun yıllardan beri serviks kanseri taramasında kullanılan PAP smear testi çok başarılı sonuçlar vermiş̦tir. Son yıllarda rutin olarak kullanılan HPV DNA testleri prekürsör lezyonların tarama ve takibinde başarılı olanaklar sağlamaktadır. Bu çalışmada PAP smear ve eş zamanlı HPV tiplendirmesi yapılan olgulara ait bulgular değerlendirilmiştir.

Yöntemler: PAP smear ve HPV testi uygulanan 6384 hasta çalışmaya alınmıștır. Bu hastalardan 886'sında $(\% 13,9)$ serviks kanseri için yüksek riskli olarak bilinen HPV tipleri bulunmuştur.

Bulgular: En sık gözlenen HPV tip 16'dır. PAP smear sonuçlarına göre normal bulunan $148(\% 16,7)$ hastada yüksek riskli HPV tipleri bulunduğu görülmüştür. Doku biyopsisi bulunan yüksek riskli HPV pozitif hastaların normal PAP smear sonuçlarına karşın 37 tanesinde LGSIL tanısı saptanmıştır. PAP smear ile HGSIL ve malign tanısı alan olguların biyopsi sonuçları ile uyumlu olduğu görülmüștür.

Sonuç: Bu çalışmanın sonuçları PAP smear testinin özellikle yüksek dereceli prekürsör lezyonlarda daha etkili olduğunu göstermektedir. PAP smear ile normal bulunan yüksek oranda hastada yüksek riskli HPV tiplerinin bulunması dikkat çekmektedir. Bu sonuç HPV testlerinin taramada önemini, sensitif ve objektif bir test olduğunu ortaya koymaktadır. Serviks kanseri taramasında PAP smear ve HPV testlerinin eş zamanlı kullanılması, bu kanserin sıklı̆̆ını ve ölüm oranlarını daha da azaltacaktır.

Anahtar kelimeler: PAP smear, HPV, serviks kanseri

DOI: $10.5798 /$ dicletip.534860

Yazışma Adresi / Correspondence: İbrahim Halil Erdoğdu, Aydın Adnan Menderes Üniversitesi Tıp Fakültesi Patoloji Ad. Aydın, Türkiye e-mail: ibrahimhalilerdogdu@gmail.com 


\title{
Comparison Of The Pathological Materials With Hpv Results In Patients With Molecular Hpv
}

\begin{abstract}
Objective: Some types of HPV play a very important role in many cancers. Almost all cervical cancers develop due to HPV. The PAP smear test, which has been used for cervical cancer screening for many years, has been very successful. HPV DNA tests, which have been used routinely in recent years, provide succesful possibilities for screening and follow-up of precursor lesions.

Methods: In this study, PAP smear and concurrent HPV typing findings were evaluated. A total of 6384 patients undergoing PAP smear and HPV were included in this study. Among these patients, 886 (13.9\%) had HPV types known as high risk for cervical cancer.

Results: The most common HPV type is 16. High-risk HPV types were found in 148 (16.7\%) patients who were normal according to PAP smear results. In contrast to normal PAP smear results in 37 patients with high risk HPV positive tissue biopsy, LGSIL was diagnosed. PAP smear and HGSIL and malignant patients were found to be compatible with the results of the biopsy.

Conclusions: The results of this study show that PAP smear test is more effective in high-grade precursor lesions. It is noteworthy that high-risk HPV types are present in a high rate of PAP smear test normal patients. This result reveals that the importance of HPV tests in screening is a sensitive and objective test. The simultaneous use of PAP smears and HPV tests in cervical cancer screening will further reduce the incidence and mortality of these cancers.
\end{abstract}

Keywords: PAP smear, HPV, cervical cancer.

\section{GíRIŞ}

Human Papilloma Virüs (HPV) 100'den fazla tipi bulunan ve birçok kanserde rol oynadığı gösterilmiş bir DNA virüsdür. Cinsel yolla en sik bulaşan hastalık olan HPV'ye cinsel yönden aktif bireylerin \%70'den fazlasinda hayatlarının bir döneminde maruz kaldığı bildirilmektedir ${ }^{1}$. Özellikle kadınlarda genital bölge (vulva, vagen ve serviks) kanserlerinde çok önemli rol oynadığı bilinen HPV, serviks kanserlerinin neredeyse tamamindan sorumludur. HPV tipleri arasında serviks kanserinde yüksek riskli olarak belirlenen (16, $18,31,33,35,39,45,51,52,56,58,59,66$ ve 68) tiplerden özellikle tip 16 serviks kanserlerinde en sık gözlenen tiptir2. Diğer HPV tipleri kanserlerle daha nadir ilişkilendirilmekle birlikte bölgesel farklılıklar da görülmektedir ${ }^{2}$. PAP smear testi taraması, yaklaşı 30 yılda serviks kanseri insidansını \%50'ye varan oranda azaltmasına rağmen, serviks kanseri kadınlarda halen kanser ölümlerinde meme kanserinden sonra 2. sırada yer almaktadır ${ }^{3}$. Çok başarılı bir tarama testi olan PAP smear değerlendirilmesinde Bethesda sistemi kullanılmaktadır. Bu sistemde yer alan bazı kategorilerde takip konusunda yaşanan sorunlar nedeniyle, bu hastalarda HPV tiplendirmesi önem kazanmıştır. Özellikle yüksek riskli HPV tespit edilmesi durumunda bu hastaların daha yakın takibi, ya da cerrahi müdahalesine karar verilebilmektedir. Son yıllarda tüm dünyada olduğu gibi ülkemizde de HPV taramasının servikal kanserlerin erken tanısında daha etkili bir yöntem olduğunu bildiren çalışmalar bulunmaktadır ${ }^{1-6}$. Konvansiyonel PAP smear taramasinda gözlenen değiş̧iklikler ile refleks HPV testi istenmesine göre, günümüzde daha sıklıkla uygulanan co-test (PAP smear+HPVtiplendirme) uygulamasının daha yüksek başarı oranına sahip olduğu bildirilmektedir ${ }^{1-5}$. Henüz tek başına HPV testinin PAP smear testinin yerini alamayacağ düşünülmekle birlikte yüksek sensitivitesi nedeniyle co-test uygulamasının servikal prekanseröz lezyonların tanı, takip ve tedavisinde daha etkili bir yol olduğu kabul 
edilmektedir. $\mathrm{Bu}$ çalıșmada, sitolojik servikal örnek sonuçları ile HPV DNA çalışılan örnekler arasındaki ilişkinin araştırılması amaçlanmıştır. $\mathrm{Bu}$ amaçla, 2016-2018 ylları arasında bölümümüzde sıvı bazlı teknik ile PAP smear incelemesi ve HPV tiplendirmesi yapılan olgulara ait sonuçlar retrospektif olarak değerlendirilmiştir.

\section{YÖNTEMLER}

Adnan Menderes Üniversitesi Hastanesi Patoloji laboratuarina 2016-2018 yılları arasında gönderilen ve HPV tiplendirmesi yapılan toplam 6384 materyal değerlendirmeye alınmıştır. Çalışma için etik kurul onayı ADÜ Etik Kurulu 10/01/2019 tarih, 2019/07 karar no ile alınmıștır. Olgulara ait materyaller sıvı bazlı ticari bir sistem (BD SurePath ${ }^{\text {TM }}$ Pap Test, ABD) ile toplanmış ve örneklerden hazırlanan preparatlar ile Bethesda Sistemi kullanılarak servikal smear değerlendirmesi yapılmıştır. Eş zamanlı olarak aynı materyaller HPV tiplendirmesi için kullanılmıştır. İlk olarak klinik örneklerde tek reaksiyonda en fazla HPV tipini amplifiye edebilecek şekilde tasarlanan primerler ile R-PCR genel bir pozitiflik/negatiflik taraması yapılarak ve sonrasinda bu testlerle pozitiflik saptanan örneklerde Pyrosequencer (QIAGEN) ile sekans analiziyle spesifik tip tayini yapılmıștır.

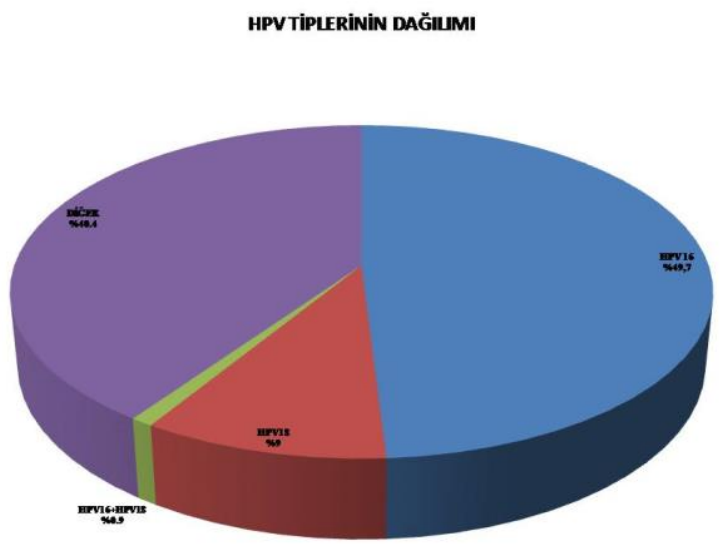

Şekil 1: HPV pozitif olgularda HPV tiplerinin dağılımı.
Bunun için; DNA İzolasyonu: Servikal sıvı bazlı smear örneklerden DNA izolasyonu QIAGEN EZ1 virüs mini kit ile QIAGEN EZ1 advanced XL otomatik cihazı ile yapılmıştır. HPV DNA PCR Aşaması: Elde edilen HPV DNA'ları ve HPV pyrosequencing kitinde (QIAGEN) mevcut HPV spesifik primerler kullanılarak PCR kuruldu.Ayrica kitte bulunan insan B-Globin geni primerleri çalışma boyunca internal kontrol olarak kullanılmıştır. PCR için mastermix hazırlanırken her bir örnek başına 20 mikrolitre AMP Buffer, 4 mikrolitre AMP nucleotide mix,2.5mikrolitre AMP dye,1.5 mikrolitre HPV sign primers, 0.8 mikrolitre AMP enzim,1.2 mikrolitreclean enzim ve 10 mikrolitre su kullanılmıştır. Örnekler Rotor Gene TM 600 cihazına aktarılarak,Rotor Gene TM 600 cihazi (QIAGEN real time PCR cycler) içerisindeki örnekler için PCR amplifikasyonları 94 derecede 1 dakika, 40 derecede 2 dakika, 72 derecede 1.5 dakika olmak üzere 40 döngü ve 72 derecede 5 dakika son uzatma olarak gerçekleștirilmiştir. Pyrosequencing: Rotor Gene 6000 amplifikasyonunun ardindan Pyromark Q24 (QIAGEN) sisteminin kullandığ 1 sentez yoluyla dizileme prensibine dayalı pyrosequencing işlemi yapılmıştır.Sekans sonucu elde edilen baz dizileriyle kütüphanedeki diziler karşılaștırılarak, pyromark sistemiyle 30 baz çifti uzunluğundaki HPV'nin aşırı değişken genom bölgesinin sekansı sağlanarak genotiplendirme gerçekleștirilmiştir.

\section{BULGULAR}

Çalışmaya alınan toplam 6384 hastanın ortalama yaşı $43.6 \quad(18-89$ yaş arası) bulunmuştur. Olguların 886'sında $(\% 13,9)$ yüksek riskli HPV pozitifliği saptanmıștır. Yüksek riskli HPV pozitif bulunan olgularda ortalama yaş $44.2 \quad(18-84$ yaş arası) bulunmuştur. Yüksek riskli HPV tiplerinden en sık HPV tip $16(\% 49,7)$ gözlenirken ikinci sıklıkta HPV tip 18 (\%9) oranında görülmüştür. Olgulardan 12 tanesinde $(\% 1,3)$ birden fazla HPV tipi pozitif bulunmuștur. En sık birliktelik 
gösteren HPV tipleri \%0,9 oranı ile HPV16+HPV 18 tipleridir. HPV sonuçları Şekil 1 'de gösterilmiştir. Bethesda sistemine göre normal kategoride raporlanan 148 (\%16,7) olguda yüksek riskli HPV pozitifliği saptanmıştır. Yüksek riskli HPV pozitif bulunan olgularda Bethesda sitemine göre; 353 olgu $(\% 39,8)$ LGSIL, 288 olgu $(\% 32,5)$ ASCUS, 49 olgu $(\% 5,5)$ HGSIL, 30 olgu $(\% 3,3)$ Malign Sitoloji, 18 olgu (\%2) ASC-H olarak raporlanmıștır. Olgulara ait PAP smear sonuçları ile HPV tiplendirmesini gösteren sonuçlar Tablo I'de özetlenmiştir. Yüksek riskli HPV pozitif bulunan 886 olgunun 142 tanesinde doku biyopsisi ile değerlendirme sonuçlarına bakıldığında; 26 olguda SCC, 29 olguda HGSIL, 76 olguda LGSIL, 11 olguda ise normal/reaktif değişiklikler olarak raporlandığı bulunmuştur. Biyopsi sonuçlarına göre SCC ve HGSIL tanısı alan 55 olgunun tamamının sitolojik olarak Malign Sitoloji, HGSIL olarak tanı aldığı ve 49 tanesinde HPV16, 4 tanesinde HPV18, 2 tanesinde HPV16+HPV18 pozitifliği bulunduğu görülmüştür. Biyopside LGSIL olarak raporlanan olgulardan 37 tanesi sitolojik olarak normal kategoride yer alırken, 14 olgu ASCUS, 25 olgu LGSIL olarak raporlanmıştır. Biyopsisi bulunan olgulara ait bulgular Tablo II'de özetlenmiştir.

Tablo 1: PAP smear sonuçları ile HPV durumunun karşılaştırılması.

\begin{tabular}{|lccc|}
\hline $\begin{array}{l}\text { PAP SMEAR } \\
\text { SONUCU }\end{array}$ & $\begin{array}{c}\text { HPV } \\
\text { POZITIF }\end{array}$ & $\begin{array}{c}\text { HPV } \\
\text { NEGATIF }\end{array}$ & TOPLAM \\
\hline $\begin{array}{l}\text { NORMAL/REAKTIF } \\
\text { DEĞiȘiKLIKLER }\end{array}$ & 148 & 5155 & 5303 \\
ASCUS & 288 & 323 & 611 \\
ASC-H & 18 & 6 & 24 \\
LGSIL & 353 & 14 & 367 \\
HGSIL & 49 & 0 & 49 \\
MALİGN SİTOLOJi & 30 & 0 & 30 \\
TOPLAM & 886 & 5498 & 6384 \\
\hline
\end{tabular}

Tablo 2: PAP smear tanısına göre doku biyopsisi bulunan olguların karşılaştırılması.

\begin{tabular}{|c|c|c|c|c|c|c|c|}
\hline \multirow[b]{2}{*}{$\begin{array}{l}\text { DOKU BIYYOPSI } \\
\text { TANISI }\end{array}$} & \multicolumn{6}{|c|}{ PAP SMEAR TANISI } & \multirow[b]{2}{*}{ TOPLAM } \\
\hline & $\begin{array}{l}\text { NORMAL } \\
\text { /REAKTiF } \\
\text { DEĞIȘiKLIKLLER }\end{array}$ & ASCUS & ASC-H & LGSIL & HGSIL & $\begin{array}{l}\text { MALIGN } \\
\text { SiTOLOJİ }\end{array}$ & \\
\hline $\begin{array}{l}\text { NORMAL } \\
\text { /REAKTIF } \\
\text { DEĞIŞ̦iKLIKLER }\end{array}$ & & 11 & & 37 & & & 48 \\
\hline LGSIL & & 14 & & 25 & & & 39 \\
\hline HGSIL & & & & & 23 & 6 & 29 \\
\hline SCC & & & & & 5 & 21 & 26 \\
\hline TOPLAM & & 25 & & 62 & 28 & 27 & 142 \\
\hline
\end{tabular}

\section{TARTIŞMA}

Günümüzde serviks kanseri gelişiminde HPV'nin mutlaka var olması gerektiği kabul edilmektedir[1]. Serviks kanseri görülme sıklı̆̆l, özellikle PAP smear tarama programının gelişmesi ile tüm dünyada çok belirgin bir şekilde azalmıştır. Ancak halen kadınlarda kanser ölümlerinde ikinci sirada yer almaktadır $^{1-7}$. ABD gibi gelişmiş sayılan bir ülkede dahi, 2018 yılında 13000'den fazla yeni servikal kanser hastası ile 4000'den fazla kadının bu kanserden öldüğü bildirilmiştir ${ }^{2}$. Bu olguların hemen tamamının da HPV nedeniyle olduğu tespit edilmiştir. Serviks kanseri ileri evrelere kadar çok fazla semptom vermemesi ve zor tedavisi nedeniyle oldukça kötü prognoza sahiptir. Bu nedenle prekanseröz lezyonların tanınması için kullanılan tarama programları büyük öneme sahiptir. Bu tarama programlarından en önemlisi şüphesiz PAP smear değerlendirmesidir. Yarım asırdan uzun süreden beri başarı ile kullanılan, serviks kanseri görülme ve ölüm oranlarını yarı yarıya azaltan PAP smear testlerinin değerlendirmesi günümüzde modifiye Bethesda sistemi ile yapılmaktadır. $\mathrm{Bu}$ sistemde yer alan ve prekürsör lezyonları tanımlayan bazı kategorilerde yer alan hastaların takip ve tedavisinde tam bir konsensus henüz sağlanamamıştır. Son yıllarda tüm dünyada olduğu gibi ülkemizde de yaygın bir şekilde 
uygulanmaya başlanan HPV tiplendirme testleri sayesinde servikal prekürsör lezyonlara yaklaşımda değişiklikler yaşanmıştır. Özellikle serviks kanseri latent döneminde hiçbir sitolojik ya da morfolojik bulgusu bulunmayan döneminde HPV'nin gösterilmesi ile bu hastaların takibinde yeni yaklaşımlar ortaya çıkarmaktadır. Serviks kanseri tarama testleri arasında en objektif ve tekrarlanabilir olan HPV DNA tespitinin daha sensitif olduğu gösterilmiştir ${ }^{8-9}$. Önceki dönemlerde, konvansiyonel smear test sonuçlarına göre şüpheli olgularda refleks test olarak daha sonradan istenen HPV testinin günümüzde servikal smearlerin sitolojik incelemesi ile eș zamanlı olarak değerlendirilmesi gerektiği bildirilmektedir. "American Society of Colpos copy and Cervical Pathology" (ASCCP) ve "American College of Obstetricians and Gynecologists" (ACOG) birlikleri, 30-65 yaş arasında kadınlarda, co-test olarak adlandırılan bu yöntem ile, beş yılda bir tarama önermektedir ${ }^{2-3}$. Yapılan çalışmalar co-test kullanımının servikal kanser taramasında servikal smear değerlendirilmesinde yaşanabilecek olan yanlış negatif ya da yanlış pozitiflik oranlarını belirgin oranda düşürdügünü göstermektedir ${ }^{10-12}$. Özellikle Bethesda sisteminde ASCUS ve AGUS kategorisinde yer alan olgularm takip ve tedavisinde co-test uygulaması ile daha etkili yaklaşımlar yapılacağ $\mathrm{kabul}$ edilmektedir. $\mathrm{Bu}$ çalışmanın sonuçlarına göre yüksek riskli HPV pozitifliği bulunan ancak servikal sitoloji ile normal kategoride raporlanan yaklaşık \%17 gibi bir oranda olgu bulunmaktadır. Bu sonuç bu olgularda önerilen tarama programlarının aksamasına yol açabilecek oranda önemlidir. Biyopsi ile değerlendirilen olgularda malignite ve yüksek dereceli displazi bulunan olgular ile servikal sitoloji sonuçları her ne kadar yüksek korelasyon gösterse de, bir tarama programı olan ve prekürsör lezyonların belirlenmesini amaçlayan servikal sitolojik materyallerde HPV değerlendirmesinin de eklenmesiyle amaca daha uygun sonuçlar alınacağı görülmektedir.
Çalışma sonuçlarına göre sitolojik olarak normal kategoride olup biyopside LGSIL tanısı alan 37 olgu bulunması HPV belirlenmesinin bu gibi olgularda yanlış negatif sonuçları engelleyebileceğini ortaya koymaktadır. Son yıllarda giderek artan oranda kullanılan ve ulusal sağlık programlarında tarama amacıyla da yer edinen HPV DNA belirlenmesinin, özellikle prekürsör lezyonların tespitinde çok önemli yer tuttuğu çalışma sonuçlarımızla da desteklenmektedir. Servikal kanser taraması amacıyla kullanılan PAP smear ve HPV DNA testinin eş zamanlı co-test şeklinde uygulanması, ülkemiz koşullarında hastaların zamanında tespit edilebilmesi, yalancı negatifliklerin azaltılması açısından daha etkili olacaktır. Özellikle sitolojik materyallerin değerlendirilmesinde yaşanan teknik sorunlar ve değerlendiren kişiye bağlı değişkenlerin azaltılarak, objektif ve sensitif bir test olan HPV DNA testinin tarama programlarında uygulanması ile servikal kanser görülme ve ölüm oranlarının daha da düşürülebileceği görülmektedir.

Sonuç olarak; PAP smear değerlendirmesi halen servikal kanser taramasında çok değerli bir yöntem olarak görülmekle birlikte co-test olarak adlandırılan eş zamanlı HPV DNA değerlendirmesi ile birlikte gerek tanı gerekse de olguların yönetiminde çok daha faydalı olacaktır. $\mathrm{Bu}$ çalışma sonuçları ülkemiz genelinden daha yüksek oranda HPV pozitifliği göstermekle birlikte, HPV pozitifliğinin gerçek oranlarının, bölgesel farklılıklarının ve HPV alt tiplerinin dağılımının belirlenebilmesi için geniş olgu serileri ile yapılacak çalışmalara ihtiyaç vardır.

Çıkar Çatışması Beyanı: Yazarlar çıkar çatışması olmadığını bildirmişlerdir.

Finansal Destek: Bu çalışma her hangi bir fon tarafından desteklenmemiştir.

Declaration of Conflicting Interests:The authors declare that they have no conflict of interest. 
Financial Disclosure: No financial support was received.

\section{KAYNAKLAR}

1. Aydoğdu SGM, Özsoy Ü. Serviks kanseri ve HPV. Androl Bul 2018; 20: 25-9.

2. Saslow D, Solomon D, Lawson HW, et all. American Cancer Society, American Society for Colpos copy and Cervical Pathology, and American Society for Clinical Pathology Screening Guidelines for the Prevention and Early Detection of Cervical Cancer. CA Cancer J Clin 2012; 62: 147-72.

3. Committee on Practice Bulletins-Gynecology. ACOG Practice Bulletin Number 131: Screening for cervical cancer. Obstet Gynecol 2012; 120: 1222-38.

4. Eroğlu C, Keşli R, Eryılmaz MA, et all. Serviks kanseri için riski olan kadınlarda HPV tiplendirmesi ve HPV sıklığının risk faktörleri ve servikal smearle ilişkisi. Nobel Med 2011; 7: 72-7.

5. Akay E, Tekelioglu F, Karaman H. Concordance of thefrequency, typing, andresults of high risk human papilloma virus in cervical cytology materials with biopsy: Retrospective analysis of 5604 patients. Annals of Medical Research 2019; 1: 1-5.
6. T. C. Sağlık Bakanlığı Sağlık İstatistikleri Yıllığı 2015. Yayın No:1054. Ankara: Sistem Ofset Basım Yayın; 2016. ss.36-7.

7. Altun E, Usta A, Bülbül ÇB, et al. HPV-DNA Alt Tiplerinin Smear ve Kolposkopik Biyopsi Sonuçlarının Korelasyonunun Değerlendirilmesi. Van Tıp Derg 2018; 25: 472-76.

8. Huh WK, Ault KA, Chelmow D, et all. Use of primaryhigh-risk human papilloma virus testing for cervical cancer screening: interim clinical guidance. Obstet Gynecol 2015; 125: 330-37.

9. Akcali S, Goker A, Ecemis T, et all. Human papilloma virus frequency and genotype distribution in a Turkish population. Asian Pac J Cancer Prev 2013; 14: 503-06.

10. Dursun P, Ayhan A, Mutlu L, et all. HPV types in Turkey: multi center hospital based evaluation of 6388 patients in Turkish gynecologi concology group centers. Turk Patoloji Derg 2013; 29: 210-16.

11. Bayram A, Derici YK, Yilmaz NO, et all. Prevalence of high-risk human papilloma virus in women from Turkey.Clin Obstet Gynecol Reprod Med 2015; 1: 84-6.

12. Katki HA, Kinney WK, Fetterman B, et all. Cervical cancer risk for women undergoing concurrent testing for human papilloma virus and cervical cytology: a population-based study in routine clinical practice. Lancet Oncol 2011; 12: 663-72. 